\title{
Evaluation of Assamese buffaloes considering important economic traits under field conditions in their home tracts
}

\author{
Shafiqul Islam \\ Assam Agriculture University, Jorhat (Assam), India \\ Safeer Alam* \\ Sher-e-Kashmir University of Agricultural Sciences \& Technology of Kashmir, Shalimar, \\ Srinagar (J\&K), India \\ Gurjeet Kaur \\ Mahatma Gandhi Chitrakoot Gramodaya Vishwavidhyalaya, Chitrakoot, Satna (M.P.), India \\ Amulya Kumar Gogai \\ Assam Agriculture University, Jorhat (Assam), India \\ *Corresponding author. E-mail: safeeralam1@gmail.com
}

\begin{abstract}
The Assamese buffaloes are being reared by the farmers/breeders for milk, meat and for draught purposes. These buffaloes are known for higher fat contents in their milk (8.5 percent on an average) and are famous in the market with a great demand and are known as "Khuti milk". They are good source of livelihood for breeders and the graziers both in its breeding tract and have attracted researchers to consider the study of some important economic traits under field conditions. The present study was organized and considered the data on a total of 324 Assamese buffaloes distributed over three districts namely Kamrup, Nagaon and Darrang in Assam covering 35 khutis (open herds) during the year 2015-16 eighteen months. The lactation milk yield of Assamese buffalo was observed as $448.38 \pm 1.67 \mathrm{~kg}$ with a lactation length of $237.06 \pm 0.74$ days and the peak yield and days to attain were measured as $3.41 \pm 0.02 \mathrm{~kg}$ and $54.16 \pm 0.19$ days respectively. The reproduction traits like age at first calving, gestation period, service period and inter-calving period were considered for the study based on the breeders' interview using pre-structured formats. The age at first calving was recorded as $52.28 \pm 0.81$ months, the gestation period was observed as $323.10 \pm 0.68$ days with an inter-calving period of $465.70 \pm 1.67$ day. The service period and the dry period for these buffalo was $171.34 \pm 0.82$ and $252.84 \pm 1.47$ days respectively. The production and reproduction performance of Assamese buffaloes need special attention to be addressed for further improvements to help a large size of population of Assam, who are entirely depending for their livelihood on these valuable AnGR (buffaloes) of Assam.
\end{abstract}

Keywords: Assamese buffaloes, Breeding tract, Economic traits, Production, Reproduction

\section{INTRODUCTION}

Majority of Indian buffaloes (63 percent) are owned by marginal and small land holders, which implies that marginal and small farmers derive a considerable proportion of their income from buffaloes. The primary importance of buffalo is more for provision of high value protein rich animal products (milk and meat), indirectly support crop production through draught power and manure, finally they are the source of income and employment for small farmers (Parashuramuluet al., 2015). The buffalo population has increased from 105.3 million (2007) to 108.7 million in $2012\left(19^{\text {th }}\right.$ Livestock census, 2012). The buffaloes of Assam are mostly of swamp type, which is still possess a semi-wild

\section{Article Info}

https://doi.org/

10.31018/jans.v12i1.2166

Received: September 16, 2019

Revised: February 21, 2020

Accepted: February 26, 2020

\section{How to Cite}

Islam, S. et al. (2020). Evaluation of Assamese buffaloes considering important economic traits under field conditions in their home tracts. Journal of Applied and Natural Science, 12(1): 19 - 24 https://doi.org/10.31018/ jans.v12i1.2166 
Islam, S. et al. / J. Appl. \& Nat. Sci. 12(1): 19 - 24 (2020)

stock census $17^{\text {th }} 18^{\text {th }}$ and $19^{\text {th }}$ respectively. These buffaloes, originally described as Swamp type based on their morphological appearance were later confirmed as riverine type based on cytogenetic analysis (Mishra et al.,2015). These buffaloes are famous for higher fat contents in their milk (8.5 percent on an average), having good market and liking among the consumers; the milk is having great demand and is known as "Khuti milk". About 17-18 percent of this milk is converted into curd and ghee, these are the reasons that these buffalo genetic resources of Assam have been considered a good source of livelihood among the breeders/graziers in its breeding tract and have attracted the researchers for further comprehensive study on production and reproduction performance under khuti management in its breeding tract. Work has been done on these lines under farm conditions on Assamese buffaloes at Assam Agricultural University, Khanapara, Guwahati, Assam (Aparna et al., 2005; Aparna et al., 2015), whereas, information under extensive management conditions are not available, hence, importance of this research is having great value for further improvement of the breed to improve production and reproduction performance of Assamese buffaloes under field conditions.

\section{MATERIALS AND METHODS}

Present study was conducted by using purposive sampling procedure survey technique in eighteen villages having highest percentage of population density of Assamese buffaloes in three districts of Assam, India, viz. Kamrup, Nagaon and Darang using stratified random sampling technique in a period of 18 months during the year 2015 \& 2016 . Three hundred forty two (342) buffalo cows were randomly selected for recording of data covering 35 khutis' (open herds) in the breeding tract. A pre -structured questionnaire and comprehensive discussions with breeders were used to collect the data related to milk production traits like lactation milk yield in $\mathrm{kg}$, lactation length in days, peak milk yield in $\mathrm{kg}$, days to attend peak milk yield, dry period in days and reproduction traits like age at first calving in days, gestation period in days, service period (days) and inter-calving period (days). In order to get logical interpretations the data collected were compiled, tabulated and subjected to appropriate statistical analysis methods described by Harvey (1975).

\section{RESULTS AND DISCUSSION}

\section{Production performance}

Lactation milk yield: The least square mean of lactation milk yield was recorded as $448.38+1.67$ $\mathrm{kg}$ for Assames buffaloes under open herd management conditions (Table 1). The results of the present study was lower than the findings of (Das, 1988, Zaman et al., 2003, Goswami, 2009 and
Arpanaet al., 2015)in swamp buffaloes of Assam, who reported the lactation milk yield as $514.16 \pm 7.67 \mathrm{~kg}, 503.89 \pm 3.87 \mathrm{~kg}, 540.34 \mathrm{kgand}$ $514.16 \pm 7.67 \mathrm{~kg}$ respectively under farm management conditions, whereas Thuchadapornet al. (2013) reported lower total lactation milk yield $(255 \pm 20.9 \mathrm{~kg})$ in Thai swamp buffaloes under intensive farm conditions. Higher milk yield in compared to the present findings was also observed by Ismaiel (1998) and (Jumaet al., 1991) in Murrah buffaloes may be due to best buffalo breed of the world maintained under farm conditions. Manzoor et al. (2013) reported quite higher milk yield $(1735.30 \pm 8.1 \mathrm{~kg}$ in 305 days and $1910.20 \pm 10.4 \mathrm{~kg}$ of total lactation yield) in registered Nili-Ravi buffaloes under field conditions, may be due to existing breed and management practices. The lower level of production in swamp buffaloes of Assam might be due to poor application of scientific breeding and management practices followed by the breeders in the breeding tract.

Lactation length: The least square mean of lactation length of the Assamese buffaloes under present study was observed as $237.06 \pm 0.74$ days and was lower than the report of Goswami, 2009 (223.80 days) whereas, lactation length reported by Das, 1988, Zaman et al., 1996, Roychoudhury, 2000 and Gogoiet al. (2002) in swamp buffaloes of Assam were higher under farm conditions. The results of Sadhana Kurrey et al., 2016 (238.6 \pm 1.7 days) in local buffaloes of Chhattisgarh plains was almost similar to the present study. In contrast AlAmin et al. (1988) in Iraqi buffalo, Srivastava et al., (1996) in Murrah buffaloes and Pathodiyaet al. (1998) in Surti buffaloes reported the lactation length as $283.7 \pm 2.47$ days, $290.26 \pm 0.42$ days and $264.60 \pm 3.0$ days respectively, were also higher than the present findings, may be due to breed type and farm management practices. Karim et al. (2013) reported lactation length as $286.12 \pm 11.27$ and $290.44 \pm 10.92$ days in two different districts of Bangladesh for indigenous breed of buffaloes under field conditions, which are also higher than the present study. Thuchadapornet al. (2012) reported in Thai swamp buffaloes as $127.50 \pm 104.6$ days of lactation length which is quite lower than the present study.

Peak yield: The least square mean of peak milk yield of the Assamese buffaloes under present study was recorded to be $3.41+0.02 \mathrm{~kg}$. Finding of the peak milk yield of the present study was lower than the findings of Gogoi ( 1994), Zaman(1996) and Goswami (2009) for swamp buffaloes of Assam who reported peak milk yield as $4.18+0.05$ $\mathrm{kg}, 4.08+0.06$ and $4.24 \mathrm{~kg}$, respectively and Azad et al., 2014 in graded Murrah, Diara and Nondescript buffaloes $(7.87 \pm 0.26,7.28 \pm 0.28$ and $5.74 \pm 0.27 \mathrm{~kg})$, whereas, PMY $(3.20 \pm 0.05 \mathrm{~kg})$ reported by Aparna et al., 2015 under farm conditions was lower than the present study in swamp 
Islam, S. et al. / J. Appl. \& Nat. Sci. 12(1): 19 - 24 (2020)

Table 1. Milk production performance of Assamese buffaloes in its breeding tract during the period 2015-16.

\begin{tabular}{|c|c|c|c|}
\hline S.N. & Production parameters & No. of observations & Mean+ SE \\
\hline 1. & Lactation milk yield $(\mathrm{kg})$ & 342 & $448.38 \pm 1.67$ \\
\hline 2. & Lactation length (days) & 342 & $237.06 \pm 0.74$ \\
\hline 3. & Peak yield $(\mathrm{kg})$ & 342 & $3.41 \pm 0.02$ \\
\hline 4. & Days to attain peak yield (days) & 342 & $54.1 \overline{6}+0.19$ \\
\hline
\end{tabular}

Table 2. Reproductive performance of Assamese buffaloes in its breeding tract during the year 2015-16.

\begin{tabular}{llll}
\hline S.N. & Reproduction parameters & No. of observations & Mean \pm SE \\
\hline 1. & Age at first calving (months) & 98 & $52.28 \pm 0.81$ \\
2. & Gestation period (days)) & 265 & $323.10 \pm 0.68$ \\
3. & Dry period (days) & 305 & $252.84 \pm 1.47$ \\
4. & Service period (days) & 315 & $177.34 \pm 0.82$ \\
5. & Intercalving period (days) & 310 & $465.79 \pm 1.67$ \\
\hline
\end{tabular}

buffaloes. Higher peak yield as compared to the present finding was reported by Chowdhary and Choudhry, 1981(in Mehsana and Surti buffalo), Prakash and Tripathy, (1987); Gajbhiye and Tripathi (1991), Gogoi, 1994 and Singh et al., 2016 (in Murrah buffalo) and Chaudhary et al., 2016 (in Nili -Ravi buffalo) which may be due to the effect of type of breed and management system.

Days to attain peak yield: The least square mean of days to attain peak yield of Assamese buffaloes was found to be $54.16 \pm 0.19$ days. The present finding is in agreement with the report of Gajbhiye and Tripathi (1991) in Murah buffaloes who reported the peak period as 54.25 days. Zaman, 1996 and Das, 2001 in Swamp buffaloes reported the peak period as $57.8+0.87$ days and $56.31 \pm 0.32$ days, respectivelywhich were slight longer. Govindiah and Rai (1986) reported peak period in medium sized Surti buffaloes as $33.0 \pm 1.0$ days and Azad et al., 2014 reported $37.6 \overline{7} \pm 0.74,41.10 \pm 0.78$ and $41.91 \pm 0.75$ (DAPY) in graded Murrah, Diara and Non-descript buffaloes, which were shorter than the present finding. Galsar et al. 2016 have reported the maximum period ( $73.13 \pm 1.49$ days) to attend the peak yield in mehsana buffalo.

\section{Reproductive performance}

Age at first calving: The least square mean of age at first calving of the Assamese buffaloes under present study was recorded as $52.28 \pm 0.81$ months. Finding of the age at first calving of the present study was lower than the findings reported by Amonge (1993); Zaman (1996); Roychoudhuri (2000) and Aparna et al. (2005) in swamp buffaloes of Assam. On the other hand Kanaujia et al. (1974) and Dahama and Malik, (1991), Sethi and Kala (2005) (55.4 \pm 0.4 months), Sadhana et al., 2016 (55.60 \pm 0.34 months) and reported higher values for the age at first calving in Indian buffaloes. However, the age at first calving in swamp buffaloes reported by Neog (1990) and Gogoi (1994) were in close conformation with the present study. Thuchadapornet al., 2012 and Goswami, 2009 reported age at first calving in swamp buffalo under intensive farm conditions as $47.10 \pm 8.0$ and 47.97 months respectively and Karim et al., 2013 reported in indigenous breed of buffalo of Bangladesh as $50.88 \pm 1.71$ months, all these findings were greater than the present finding in Assamese buffaloes.

Gestation period: Least squares mean of gestation period was reported to be $323.10 \pm 0.68$ days. The gestation period of the present study was in close agreement with findings of Amonge, 1993 and Zaman,1996 in swamp buffaloes of Assam. On the other hand Al-Amin et al., 1988 in Iraqi buffaloes, Tailor and Jain, 1993 in Mehsana buffaloes, Pyneet al., 1992 in Murrah buffaloes observed shortest gestation period than the present findings.

Intercalving period: Least squares mean of intercalving period was found as $465.79 \pm 1.67$ days in Assamese buffaloes in its breeding tract. Similar results were also reported by Pathodiaet al., 1992in Surti buffaloes and Das, 1988 in swamp buffaloes. However, Dhanani et al., 1980 observed a shorter inter-calving period in Kundi buffaloes and Goswami, 2009 reported 445.30 months in Swamp buffalo, which is also less than the present finding similarly Sinha et al., 2014 reported 436.34 \pm 5.32 days in graded murrah buffalo. On the contrary, Kandasamy et al., 1993; Pyneet al., 1992; Zaman, 1996 and Roychoudhuri, 2000), Sethi and Kala, 2005 (511 \pm 4.5 days), Sinha et al., 2014 (747.88 \pm 5.66 days in Diara and $477.21 \pm 5.43$ days in Non-descript buffaloes) and Aparna et al. (2015) reported longer inter-calving period in different breeds of buffaloes, may be due to the breed type and management practices, whereas, gestation period reported by Thuchadapornet al., 2012 (321.4 \pm 11.3 days) in Thai swamp buffaloes under intensive farm conditions, and Karim et al., 2013reportedobservations as $319.56 \pm 5.93$ and $319.12 \pm 4.69$ days in indigenous buffaloes of two different districts of Bangladeshwere lower than the present study.

Service period: Under present study in Assamese buffaloes, the least squares mean of service period was found to be $171.34 \pm 0.82$ days in Assamese buffaloes under field conditions. The present value was corroborated well with the findings of Mourad et al., 1991 in Egyptian buffaloes, Pyneet al., 1992 in Murrah buffaloes and Zaman, 1996 in swamp buffaloes of Assam, Thuchdapor- 
net al., 2012 in Thai buffaloes and Aparna et al., 2015 in Assamese swamp buffaloes during most calving season (August to January). Longer service period than the present study was reported earlier by Narasimharao and Ramachandrarao, 1996 in Murrah buffaloes, Ahmad et al., 1983 in Nili Ravi buffaloes and Tailor and Jain, 1993 in Surti and Mehsana buffaloes. However, Dhanani et al., 1998 in Jaffrabadi buffaloes and Pathodiyaet al., 1998 Surti buffaloes observed shorter service period.

Dry period: In present study, the least square mean for dry period in Assamese buffaloes was recorded as $252.84+1.47$ days. The present value for dry period in Assamese buffaloes was well corroborated with the reports of Das, 1998 in swamp buffaloes, where as Sethi and Kale, 2005 reported $193.4 \pm 4.7$ days which is shorter period than the findings of present study and Goswami, 2009 reported even more lesser period (152.09 days) in Swamp buffalo. Sinha et al., 2014 reported dry period (DP) of graded Murrah, Diara and non-descript buffaloes as $135.84 \pm 6.02$, $155.26 \pm 6.39$ and $159.37 \pm 6.14$ days respectively. Galsar et al., 2016 observed $158.49 \pm 5.15$ days of dry period in Mehsana buffalo which is also less than the present study. Longer dry period was observed by Shrestha and Yazman, 1998 in Nepali swamp buffaloes. Tailor and Jain, 1993 in Surti buffaloes, Zaman, 1996 and Roychoudhuri, 2001 in swamp buffaloes observed shorter dry period than the present findings.

\section{Conclusion}

Assamese buffaloes are mostly reared by the Tribes, Nomads and Landless population in the breeding tract for sole source of livelihood in Assam. The productive and reproductive performance of this breed is needed to be addressed based on present study under field conditions for further improvement of the breed and its conservation to help the breeders/stakeholders. The population of Assamese buffaloes estimated to be around 6,78,000 (2003), 5,00,000 (2007) and $4,35265(2012)$ as per livestock census $17^{\text {th }}, 18^{\text {th }}$ and 19 respectively, means continuous decline in the population due to various reasons has attracted the attention to conducted study on production performance of the breed. The mean lactation milk yield was $448.38 \pm 1.67 \mathrm{~kg}$, the peak yield $3.41 \pm 0.02 \mathrm{~kg}$, to attain peak yield it took $54.1 \overline{6}+0.19$ days and the lactation length was $237.0 \overline{6}+0.74$ days. The overall reproduction performance of the breed was $52.28 \pm 0.81$ months on age at first calving, gestation period $323.10 \pm$ 0.68 days, dry period $252.84+1.47$ days, Service period $177.34 \pm 0.82$ days and Inter-calving period $465.79 \pm 1 . \overline{6} 7$ days (Table 2 ). The production and reproduction performance of Assamese buffaloes are better under organized farm conditions than the present study under field conditions, keeping in view it is suggested that using technological interventions/research findings may be improved the performance of the breed in its breeding tract and ultimately income and livelihood can be enhanced of the breeders/farmers of all four district under study.

\section{REFERENCES}

1. Al-Amin, S.K., Hanna, W.J. and Al-MarashiA.M (1998). Gestation period and birth weight in Iraqi Buffaloes. Indian J. Anim. Sci., 58:942-945

2. Ahmad, N., Khan, I. M., ChoudhuryR. A., andAhmedW. (1983). Reproductive efficiency of Nili Ravi buffaloes in Pakistan. Indian J. Anim. Sci., 53: $1066-1068$

3. Amonge, T.K. (1993). Aspects of productive and reproductive behavior of swamp buffaloes under khuti system of management in Assam. Ph. D. Thesis. Submittedto Assam Agril. Uni. Guwahati, Assam

4. Aparna Das, Das, D., Goswami,R.N., Das,G.C. and Bhuyan D. (2005). Performance of Swamp buffalo of Assam in respect of some economically important traits of reproduction under farm conditions. Buffalo Bulletin, 24: 25-28

5. Aparna Das, Das, D., Goswami,R.N., Das,G.C., Bhuyan, D. and Sinha, S.(2015). Effect of nongenetic factors on lactation milk yield and peak yield of Swamp buffaloes and their repeatability. Indian Journal of Animal Research,49: 418-419

6. Azad, K.K., Shankar, S., Mandal, K.G., Sinha, R.K., Kumar, B. and Verma, S.B. (2014). XI National Symposium on Harmonizing Phenomics and Genomics for Sustainable Management of Livestock for Upliftment of Rural Masses (February 06-07, 2014) held at National Bureau of Animal Genetic Resources, Organized by Society for Conservation of Domestic Animal Biodiversity: 139(SOCDAB2014:2.21)pp.

7. Chaudhary, M., Sikka, A.K., Singh, K.P. and Pander, B.L. (2016). Genetic studies on production and fertility traits in Nili-Ravi buffaloes. XIII Annual Convention of Society for Conservation of Domestic Animal Biodiversity (February 11-12, 2016) held at SKUASTJammu and sponsored by ICAR, DBT and NABARD: 206(057) pp.

8. Chowdhary, M.S. and Choudhry, A.C. (1981). Studies on peak yield and days to attain peak yield in Mehsana and Surtibuffaloe. Indian vet. J., 58:203207

9. Dahama, R.S. and Malik, R.S.(1991). Inheritance of peak yield in Indian buffaloes. Indian Vet. Med. J., 15 (3): Anim. Breed. Abstr.,81: 1356

10.Das, D. (1988). Performances of swamp buffaloes under agro-climatic condition of Assam. I-world buffalo Congress: 143pp.

11.Das, G.C., Deori, S., Das, B.K. and Goswami, R.N. (2007). Studies on certain Seminal characteristics of swamp buffaloes of Assam. The Indian Veterinary Journal, 84(10): 1052-1053

12.Dhanani, J., Unnar, A., Sami, M.U., Kaka, I. and Khangrani, S. (1980). Reproduction in Kundi buffalo. Abstr. : II World Buffalo Congress: 24pp.

13.Gajbhiye, P.U. and Tripathi, V.N. (1991). Factors affecting peak yield and days to main peak yield in Murrah buffaloes. Asian J. Dairy Research 10: 166168. 
Islam, S. et al. / J. Appl. \& Nat. Sci. 12(1): 19 - 24 (2020)

14.Galsar, N.S., Ramsinhshah, R., Prasadpandey, D., Chaudhary, J.D. and Prakashgupta, J. (2016). Evaluation of Performance potential of Mehsana buffaloes in an Organized herd. XIII Annual Convention of Society for Conservation of Domestic Animal Biodiversity (February 11-12, 2016) held at SKUAST-Jammu and sponsored by ICAR, DBT and NABARD: 197 (039)pp.

15.Gogoi, P.K. (1994). Evaluation of genetic potential of swamp buffaloes and riverine buffaloes of Assam with respect to certain production and rproductive traits. Ph. D. thesis submitted to Assam Agril. Uni. Guwahati-22

16.Gogoi, P.K., Das, D., Goswai, R.N., Nahardeka, N. and Das, C.G. (2002). Studies on age at first calving in Murrah and Surti buffaloes maintained in Assam. Indian Vet. J. 79: 854-855.

17.Goswami, R.N. (2009). Status and Potentials in Animal Genetic Resources of North Eastern India. National Symposium on Livestock Biodiversity Conservation \& Utilization: Lessons from Past and Future Perspectives (February 12-13, 2009) held at National Bureau of Animal Genetic Resources, Organized by Society for Conservation of Domestic Animal Biodiversity: 43-51pp.

18.Govindiah, M.G. and Rai A.V. (1986). Effect of month of calving on lactation parameters in Surti buffaloes. Indian J. Dairy Sci., 39:226-230

19. Harvey, V.R. (1975). Least square analysis of data with unequal subclass numbers. A.R.S., U.S.D.A., Beltsville, Maryland. 20:8

20.Livestock census, 2012. $19^{\text {th }}$ Livestock Census, Department of A.H., Dairying and Fisheries, Ministry of Agriculture and Farmers' welfare, Gol, New Delhi.

21.Ismaiel, N.J.(1988). Performance of buffaloes in southern Iraq. II world buffalo congress, 83-92pp.

22.Juma, K.H., Baghdsar, G.A. and Said S.I.(1991). Iraqi Buffaloes II. Some factors affecting milk yield, Buffalo Bulletin,11:27-29 (Anim.Breed.Abstr., 61: 4239)

23.Kanaujia, A.S., Balaine, D.S. and Rathi, S.S.(1974). Factors affecting some economic traits of reproduction in Indian buffaloes. Indian J. of Dairy Sci., 28:5762

24.Kandasamy, N., Lagaithan, V.W. and Krishnan, A.R. (1993). Non genetic factors affecting calving interval and dry period of Murrah buffaloes. Buffalo Bulletin, 12: $63-65$

25.Karim, M.R., Hossain, M.Z., Islam, M.R., Pervin, M.S. and Matin, M.A.(2013). Reproductivity, Productivity and management system of indigenous buffalo (Bubalusbubalis) cows in coastal areas of pirojpur and Borguna districts of Bungladesh. Progressive Agriculture, 24: 117-122

26.19 ${ }^{\text {th }}$ Livestock Census 2012, Department of Animal Husbandry, Dairying \& Fisheries, Ministry of Agriculture, Gol, New Delhi.

27.Manzoor Ahmad, J., Khalid, S., Wasim, M. Fayyaz and Muhammad, H.K.(2013). Some Environmental factors affecting performance traits in registered NiliRavi buffalo population at field area of Pakistan. Buffalo Bulletin, 32: 764-767

28.Mishra, B.P., Dubey, P.K., Prakash, B., Kathiravan, P., Goyal, S., Sadana, D.K., Das, G.C., Goswami, R.N., Bhasin, V., Joshi, B.K. and Katariya, R.K. (2015). Genetic analysis of river, Swamp and hybrid buffaloes of North-east India throw new light on phy- togeography of water buffalo (Bubalusbubalis). Journal of Animal Breeding and Genetics, 132: 454-466

29.Mourad, K.A., Mahamad, M.M. and Khattab, A.S. (1991). Genetic parameters for milk production traits in a closed herd of Egyptian buffaloes. EgyptianJ. Ani. Prod. (Anim. Breed. Abstr., 62: 201)

30.Narasimharao, A.N. and Ramamohanrao, H.(1996). Effect of service period, dry period and sex of calf on peak yield in Murrah buffaloes. Indian Vet. J., 73: $1296-1297$

31.Neog, P. K. (1990). Studies on certain production and reproduction traits in Murrah and Surti buffaloes in Assam. M.V.Sc. thesis, submitted to Assam Agril. University, Guwahati, Assam

32.Parashuramulu, S., Swain, D.P., Swain, S., Dominic, G.S., Pradhan, S. R. and V. K. Bidarkar (2015). Role of Buffaloes in Indian Economy \& their importance and constrains in India. Pashudhan, 41:1\&7

33.Pathodiya, O. P., Jain, L.S., Tailor, S.P. and Singh, S.P. (1998). Genetic studies of some economic traits of Surti buffaloes. Indian J. dairy Sci., 51: 218 -224

34.Prakash, A. and Tripathi, V.N. (1987). Genetic study of peak yield in Murrah buffaloes. Indian J. Dairy Sc. 40 (1): 45-48.

35.Pyne, A. K., Dattagupta, R. and Roy, S.K. (1992). Effect of season of calving on service period, gestation period and calving interval in Murrah buffaloes in West Bengal. Indian Journal of Anim. Prod. \& Mgt., 8: 193-195

36. Roychoudhury, D. (2000). Studies on certain physical, biochemical and performance traits of swamp buffaloes. M.V.Sc. Thesis submitted to Assam Agril. University, Guwahati, Assam.

37.Roychoudhury, G. (2001). Studies on certain physical, biochemical and performance traits of swamp buffaloes. M..Sc. Thesis. Submitted to Assam Agril. Uni., Guwahati, Assam

38.Sadhana, K., Mukherjee, K., Singh, M., Barwa, D.K. and Jain, A. (2016). Studies on some economic traits of local buffaloes of Chhattisgarh plains. XIII Annual Convention of Society for Conservation of Domestic Animal Biodiversity (February 11-12, 2016) held at SKUAST-Jammu and sponsored by ICAR, DBT and NABARD: 205(057)pp.

39.Sethi, R.K. and Kala, S.N. (2005). Buffalo Wealth and Genetic Improvement Programmes in India. VIII National Conference on Animal Genetics and Breeding: National Livestock Breeding Policy (March 08$10,2005)$ held at Central Institute for Research on Goats, Makhdoom, Mathura, Organized by Indian Society of Animal Genetics and Breeding: 50-59pp.

40.Shrestha, N. and Yazman, J.A. (1988). Performance of Murrah cross buffalo at the Lampathan Livestock Farm. Abstract: /l World Buffalo Congress, pp. 177

41.Singh, M., Singh, A., Gupta, A.K., Singh, A., Dash, S.K. and Gupta, A. (2016). Comparative evaluation of different lactation curve models in prediction of monthly test-day milk yields in Murrah buffaloes. XIII Annual Convention of Society for Conservation of Domestic Animal Biodiversity (February 11-12, 2016) held at SKUAST-Jammu and sponsored by ICAR, DBT and NABARD: 207(060) pp.

42.Sinha, R., Shankar, S. and Azad, K.K. (2014). Genetic Analysis of Dry Period and Calving Interval of Buffaloes. XI National Symposium on Harmonizing Phenomics and Genomics for Sustainable Management of Livestock for Upliftment of Rural Masses (February 
Islam, S. et al. / J. Appl. \& Nat. Sci. 12(1): 19 - 24 (2020)

06-07, 2014) held at National Bureau of Animal Genetic Resources, Organized by Society for Conservation of Domestic Animal Biodiversity: 145 (SOCDAB2014:2.30)pp.

43.Srivastava, A.K., Singh, C.S.P., Verma, S.K. and Dutta, O.P. (1996). Dry period and Calving interval in buffaloes maintained under farmers' managemental conditions. J. of Research 8(2): 193-195

44.Tailor S.P. and Jain, L.S. (1986). Factors affecting reproduction traits in medium sized buffaloes. Livestock Adviser, 11: 45-48

45.Tailor S.P. and Jain, L.S. (1993). Seasonality in buf- falo reproduction. Livestock Adviser, XVIII: 5-9

46. Thuchadaporn, C., Ranchuan, H., Fabrio, D. R., Mangkol, T. and Siriwat, S. (2012). Reproductive and Dairy performance of Thai swamp buffaloes under intensive Farm management. Thai J. Vet. Med., 42: 81-85

47.Zaman, G.U. (1996). Genetic studies on swamp buffaloes of Assam, Ph.D. Thesis, submitted to Assam Agril. Uni., Guwahati, Assam

48.Zaman, G., R., Goswami, N. and Aziz, A. (2003). Production performances of Swamp buffaloes of Assam. Indian Vet. Journal, 80: 1070-1071 